\title{
Biological activities and physicochemical properties of polysaccharides from Gloiopeltis furcata prepared by using various enzymes
}

\author{
Dae-Hoon Lee, Joo-Heon Hong * \\ Department of Food Science and Technology, Catholic University of Daegu, Gyeongsan 38430, Korea
}

\section{효소종류에 따른 불등풀가사리 유래 다당류의 이화학적 특성 및 생리활성}

\author{
이대훈 · 홍주헌 * \\ 대구가톨릭대학교 식품공학전공
}

\begin{abstract}
In this study, the biological activities and physicochemical properties of polysaccharides from Gloiopeltis furcata were investigated. Polysaccharides were isolated by enzymes treatment (celluclast, flavourzyme, papain, termamyl, viscozyme) followed by ethanol precipitation and lyophilization. The yield of polysaccharides by enzymes treatment group were 52.8-66.4\%. The major constituents in viscozyme treatment group were total sugar (71.04\%), protein $(7.22 \%)$, uronic acid $(23.18 \mathrm{~g} / 100 \mathrm{~g})$, and sulfate $(28.27 \%)$, respectively. The DPPH radical scavenging activity and ferric reducing antioxidant potential of the viscozyme treatment group at $5 \mathrm{mg} / \mathrm{mL}$ were $23.10 \%$ and 218.50 $\mu \mathrm{M}$, respectively. The protective effects against $\mathrm{H}_{2} \mathrm{O}_{2}$-induced cytotoxicity in $\mathrm{L132}$ cell of viscozyme treatment group at $1 \mathrm{\mu g} / \mathrm{mL}$ was $85.64 \%$. The viscozyme treatment group increased the production of nitric oxide (NO) in a dose-dependent manner. The antitumor activity of viscozyme treatment group (at $25 \mu \mathrm{g} / \mathrm{mL}$ ) in A549, HeLa, SNU719 and MCF7 was $69.57 \%, 52.74 \%, 61.06 \%$ and $68.64 \%$, respectively. All of data showed that the biological activities and chemical characteristics of enzymes treatment group are higher than that of the control group. The polysaccharides isolated from Gloiopeltis furcata investigated herein are useful as functional materials agents.
\end{abstract}

Key words : Gloiopeltis furcata, enzymatic hydrolysis, polysaccharides, biological activities, physicochemical properties

\section{서 론}

해양생물은 육상식물과는 다른 생육 환경 및 진화과정에 의해 구성성분이 상이하고 이들이 생산하는 대사산물에 새로운 물질이 많아 다양한 분야에서 활발한 연구가 이루어 지고 있다(1). 해양생물자원에 의한 다양한 생리활성은 해 면동물, 해조류, 산호 등의 해양생물이 외부 물질의 방어를 위하여 만들어내는 대사산물로 여겨지고 있는 관계로 천연 물 유래 기능성 개발에 활용될 것으로 기대되고 있다(2).

*Corresponding author. E-mail : jhhong@cu.ac.kr

Phone : 82-53-850-3218; Fax : 82-53-850-3218

Received 1 June 2017; Revised 15 June 2017; Accepted 19 June 2017.

Copyright (c) The Korean Society of Food Preservation. All rights reserved.
해양생물자원 중 해조류는 한국과 일본에서 식용으로 이용되고 있으며, 유럽 등 다른 나라에서 알긴산, 카라기난 및 한천 등의 식품 첨가물 원료 및 비료 등으로 사용되고 있다 $(3,4)$. 이들 해조류는 근래 들어 건강과 웰빙에 대한 관심이 깊어지면서 생체 조절기능을 갖는 기능성 소재로 각광받고 있으며, 풍부한 다당류를 함유하고 있어 일반식 품, 건강기능식품, 화장품, 의학품 및 공업용 원료 등으로 다양하게 이용되고 있다(5).

홍조류는 홍조식물문(Rhodophyta)에 속하는 조류로써, 약 400 속 4,000 여 종이 알려져 있으며 건조 중량 기준으로 40-75\%의 탄수화물을 함유하고 있고 탄수화물의 주요 구 성성분으로는 다당류인 셀룰로오스, 자일란, 한천 및 카라 기난 등이 있다(6). 홍조류에 속하는 불등풀가사리(Gloiopeltis furcata)는 풀가사리과(Endocladiaceae) 계통으로 조간대의 바위나 돌 위에서 자라며 한국, 일본, 미국 태평양 연안 
등에 분포하고 있다. 불등풀가사리의 형태는 적갈색을 띠 고 외부는 가죽질의 긴 막대 모양으로 속은 비어 있고 가늘 다. 또한, 점액질이 풍부하며 풀가사리와 외형상 유사하나 줄기의 속이 비어 있는 차이점이 있다(7). 불등풀가사리에 주로 함유되어 있는 다당은 자연에 널리 분포하고 있으며 해양생물에 의해 생산되기도 하고 식물과 해조류로부터 파생 된다. 이러한 다당은 sulfate 함량, 분자량, 당골격의 sulfate 위치, 당성분 및 glycosidic branching에 의존적으로 항산화 및 항암 등을 나타내고 있다(8).

해조류 유래 유용물질 추출에서 가장 문제가 되는 것은 단단한 조체와 세포벽 충전 물질인 세포 간 다당의 유용성 분을 추출하기가 어렵고 많은 비용을 필요로 하고 있다(9). 해조류에서 유효성분을 분리하기 위한 물리 화학적 방법으 로 고온고압, 산과 알카리 처리를 이용하는 방법을 주로 사용하고 있으나, 낮은 수율, 환경오염 및 독성에 의해 새로 운 추출 방법의 대안이 요구되어 지고 있다(10). 이러한 단점을 보완하기 위해 최근 효소적 가수분해방법을 사용하 여 세포벽에 있는 섬유질이나 당단백질 혹은 고분자 물질 등을 분해시키는 작용을 하여 활성물질들이 원활하게 추출 될 수 있도록 유도하는 친환경적인 추출방법에 대한 연구가 이루어지고 있다(11).

따라서, 본 연구에서는 불등풀가사리 유래 유용물질인 다당류의 활용 증진을 위해 상업적으로 판매되고 있는 다양 한 효소를 처리하여 황산다당류를 분리하였으며, 분리한 다당류의 이화학적 특성 및 생리활성에 대해 조사하였다.

\section{재료 및 방법}

\section{실험재료}

본 실험에 사용한 불등풀가사리는 전라남도 완도군에서 채취한 것을(유)제일물산에서 구입하여 본 실험에 사용하 였다. 구입한 불등풀가사리는 흐르는 물에 세척하고 $50^{\circ} \mathrm{C}$ 열풍 건조기(OF-22, JEIO TEC, Daejeon, Korea)로 건조한 다음 분쇄기(FM-909W, Hanil, Co., Sejong, Korea)로 분쇄한 후 60 mesh 이하의 분말로 제조하여 $-20^{\circ} \mathrm{C}$ 이하에 보관하면 서 효소분해용 시료로 사용하였다.

\section{다당류 제조}

불등풀가사리 유래 다당류를 분리하기 위하여 건조된 분말 $5 \mathrm{~g}$ 에 증류수를 고형분 대비 50 배 첨가한 다음 5 종의 효소 flavourzyme(Flavourzyme $500 \mathrm{MG}, 500 \mathrm{LAPU} / \mathrm{g}$ ), papain(Collupulin MG, $5280 \mathrm{NF} / \mathrm{mg}$ ) termamyl(Termamyl $120 \mathrm{~L}, 120 \mathrm{KNU} / \mathrm{g}$ ), celluclast(Celluclast $1.5 \mathrm{~L}, 700 \mathrm{EGU} / \mathrm{g}$ ) 및 viscozyme(Viscozyme L, $100 \mathrm{FBG} / \mathrm{g}$ )을 Novozymes Co. (Bagsvaerd, Denmark)에서 구입하여 기질 대비 $3 \%$ 첨가하 여 shaking incubator(BS-31, Jeio Tech, Daejeon, Korea)에서
$150 \mathrm{rpm}, 60^{\circ} \mathrm{C}, 14$ 시간 교반 하였다. 교반한 시료는 원심분 리 $(3,000 \times \mathrm{g}, 30$ 분 $)$ 한 다음 회수하여 상등액을 감압 농축기 (Model N-1N, Eyela Co., Tokyo, Japan)로 $60^{\circ}$ Brix가 될 때까지 농축하였다. 농축액은 5 배량의 에탄올을 첨가하여 24 시간 교반하고 원심분리 $(3,000 \times g, 30$ 분 $)$ 하여 조다당류 를 회수하였고 동결건조(FreeZone 2.5, Labconco Co., Kansas, MO, USA)하여 $-70^{\circ} \mathrm{C}$ 이하에 보관하면서 분석용 시료로 사용하였다.

\section{다당류 분리 수율}

다당류 분리 수율은 동결건조기(Freezone 2.5, Labconco $\mathrm{Co}$.)를 이용하여 건조한 후 분리된 다당류의 제조에 사용한 원료 건물량에 대한 고형분 함량으로 나타내었다.

\section{총 당 및 총 단백질 함량}

총 당 함량 분석은 Saha와 Brewer(12)의 방법에 따라 페 놀-황산법으로 분석하였다. 즉 $5 \%$ phenol $1 \mathrm{~mL}(\mathrm{w} / \mathrm{v}$, Duksan Pure Chemicals, Seoul, Korea)와 sulfuric acid(Duksan Pure Chemicals) $5 \mathrm{~mL}$ 를 시료 $1 \mathrm{~mL}$ 와 반응시킨 후 분광광도계 (Ultraspec 2100pro, Amersham Co., Uppsala, Sweden)를 사 용하여 $525 \mathrm{~nm}$ 에서 흡광도를 측정하고 glucose(SigmaAldrich Co., St. Louis, MO, USA)를 표준곡선으로 이용하여 계산하였다.

총 단백질 함량은 Lowry 등(13)의 방법으로 측정하였으 며 bovine serum albumin(BSA, Sigma-Aldrich Co.)을 표준 곡선으로 이용하여 계산하였다.

\section{Uronic acid 함량 및 sulfate 함량}

Uronic acid 함량은 Cesaretti 등(14)의 방법에 따라 분석 하였다. 즉, $25 \mathrm{mM}$ sodium tetraborate(Sigma-Aldrich Co.)를 진한 황산 용액으로 제조한 후 이 용액 $0.2 \mathrm{~mL}$ 와 시료 0.05 $\mathrm{mL}$ 를 96-well plate에 넣고 잘 섞은 후 $100^{\circ} \mathrm{C}$ 에서 10 분간 가열하였다. 그 다음 상온에서 15 분 방냉한 후 $0.125 \%$ carbazole(Sigma-Aldrich Co.) $0.05 \mathrm{~mL}$ 를 가하고 $100^{\circ} \mathrm{C}$ 에서 10 분간 가열 후 상온에서 15 분 방냉하여 microplate reader(Asys UVM340, Biochrom, Eugendorf, Austria)로 550 $\mathrm{nm}$ 에서 흡광도를 측정하고, galacturonic acid(SigmaAldrich Co.)를 이용하여 작성한 표준곡선으로부터 함량을 계산하였다.

황산기 함량분석은 Dodgson과 Price(15)의 방법으로 분 석하였다. 시료 $3 \mathrm{mg}$ 에 $6 \mathrm{~N}$ hydrochloric acid(HCl, Duksan Pure Chemicals.) $10 \mathrm{~mL}$ 를 가한 후 $110^{\circ} \mathrm{C}$ 에서 6시간 가수분 해하였다. 가수분해한 시료 $0.2 \mathrm{~mL}$ 에 $3 \%$ trichloroacetic $\operatorname{acid(TCA,~Acros~organics,~Geel,~Belgium)ㄹㅡㄹ~} 3.8 \mathrm{~mL}$ 및 $\mathrm{BaCl}_{2}$-gelatin 용액 $1 \mathrm{~mL}$ 를 가하고 $25^{\circ} \mathrm{C}$ 에서 15 분간 반응한 다음 분광광도계(Ultraspec 2100pro, Amersham Co.)를 사용 하여 $360 \mathrm{~nm}$ 에서 흡광도를 측정하였으며, potassium 
sulfate(Sigma-Aldrich Co.)를 이용하여 작성한 표준곡선으 로부터 함량을 계산하였다.

\section{DPPH radical 소거활성}

DPPH radical 소거활성 측정은 1,1-diphenyl-2-picrylhydrazyl (DPPH, Sigma-Aldrich Co.)의 환원력을 이용하여 측정하였 다(16). $5 \mathrm{mg} / \mathrm{mL}$ 농도로 희석한 시료 $1 \mathrm{~mL}$ 에 $4 \times 10^{-4} \mathrm{M}$ DPPH 용액(99.9\% ethyl alcohol에 용해) $1 \mathrm{~mL}$ 를 가하여 총액의 부피가 $2 \mathrm{~mL}$ 가 되도록 하였다. 이 반응액을 약 10 초 간 혼합하고 실온에서 30 분 방치한 다음 $525 \mathrm{~nm}$ 에서 분광 광도계(Ultraspec 2100pro, Amersham Co.)를 사용하여 측정 하였으며, DPPH radical 소거활성은 시료의 첨가 전과 후의 차이를 아래와 같이 백분율로 나타내었다.

DPPH Radical scavenging activity $(\%)=\left(1-\frac{\text { sample absorbance }}{\text { control absorbance }}\right) \times 100$

\section{FRAP}

Ferric reducing antioxidant potential(FRAP)법에 의한 환 원력은 Benzie와 Strain(17)의 방법에 따라 $300 \mathrm{mM}$ acetate buffer(pH 3.6), $40 \mathrm{mM} \mathrm{HCl}$ 에 용해한 $10 \mathrm{mM} \mathrm{TPTZ}$ (2,4,6-tripyridyl-s-triazine, Sigma-Aldrich Co.) 용액 및 20 $\mathrm{mM} \mathrm{FeCl} \cdot 6 \mathrm{H}_{2} \mathrm{O}$ (Sigma-Aldrich Co.)를 각각 $10: 1: 1(\mathrm{v} / \mathrm{v} / \mathrm{v})$ 의 비율로 혼합하여 $37^{\circ} \mathrm{C}$ 의 수옥상에서 가온한 것을 FRAP 기질 용액으로 사용하였다. 96-well plate에 $5 \mathrm{mg} / \mathrm{mL}$ 농도로 희석한 시료액 $25 \mu \mathrm{L}$ 와 FRAP 기질액 $175 \mu \mathrm{L}$ 를 차례대로 혼합하여 $37^{\circ} \mathrm{C}$ 에서 4 분간 반응 시킨 후 microplate reader(UVM-340, ASYS Co.)를 사용하여 $590 \mathrm{~nm}$ 에서 흡광 도를 측정하였다.

세포주 및 세포 배양 방법

실험에 이용한 세포주는 폐 정상세포(L132), 마우스 대식 세포(RAW264.7), 인간 폐암세포(A549), 인간 위암세포 (SNU719), 인간 자궁경부암세포(HeLa) 및 인간 유방암세 포(MCF7)를 한국 세포주 은행(KTCC, Seoul, Korea)에서 구입하여 사용하였다. L132, A549, SNU719, HeLa 및 MCF7 세포주는 RPMI 1640(Welgene, Daegu, Korea) 배지 를 사용하였고 RAW264.7 세포주는 DMEM(Welgene) 배지 를 이용하여 각각 $10 \%$ fetal bovine serum, $1 \%$ penicillinstreptomycin(Gibco BRL Co., Grand Island, NY, USA)을 첨가하여 사용하였다. 세포는 모두 $37^{\circ} \mathrm{C}, 5 \% \mathrm{CO}_{2}$ incubator (MCO-18AIC, SANYO Co., Sakata, Japan)에 적응시켜 각각 배양시켰다.

\section{세포 독성}

L132 및 RAW264.7 세포에 대한 독성은 MTT assay로 측정하였으며, 배양된 세포주를 $5 \times 10^{4} \mathrm{cell} / \mathrm{well}$ 의 농도로 조정하여 96-well plate에 $100 \mu \mathrm{L}$ 씩 첨가하여 24시간 배양하
고, 이후 새로운 배지에 시료를 농도별로 처리한 다음 24시 간 동안 배양하였다. 배양 후 PBS 완충용액에 녹인 methyl thiazol-2-YL-2, 5-diphenyl tetrazolium bromide(MTT 5 $\mathrm{mg} / \mathrm{mL}$, Sigma-Aldrich Co.)용액을 각 well에 $10 \mu \mathrm{L}$ 씩 첨가 하고 다시 4시간 동안 배양하여 MTT가 환원되도록 하였다. 이후 상등액을 완전히 제거하고 dimethyl sulfoxide(DMSO, Junsei Chemical Co., Tokyo, Japan) $100 \mu \mathrm{L}$ 를 각 well에 첨가 하여 10 분간 반응시켜 formazan 결정을 완전히 용해한 다음 microplate reader(UVM-340, ASYS Co.)를 이용하여 $540 \mathrm{~nm}$ 에서 흡광도를 측정하였다.

\section{산화적 손상에 대한 세포보호 효과}

$\mathrm{L} 132$ 세포에 $\mathrm{H}_{2} \mathrm{O}_{2}$ 에 의해 유도된 산화적 손상에 대한 세포보호 효과를 측정하기 위해 MTT assay를 실시하였으 며, L132 세포를 96-well plate에 $5 \times 10^{4}$ cells/well로 분주하 고 incubator에서 24시간 동안 배양하였다. 배양 후 시료를 처리하고 24시간 동안 배양한 다음 $\mathrm{H}_{2} \mathrm{O}_{2}$ (Duksan Pure Chemicals.)를 $1 \mathrm{mM}$ 의 농도로 첨가하고 30 분간 처리 후 L132 세포에 MTT( $5 \mathrm{mg} / \mathrm{mL}$, Sigma-Aldrich Co.)를 처리하 여 $37^{\circ} \mathrm{C}$ 에서 4 시간 반응시켰다. 그 후 상등액을 제거하고 각 well에 $200 \mu \mathrm{L}$ 의 dimethyl sulfoxide(DMSO)를 첨가한 다음 microplate reader(UVM-340, ASYS Co.)를 사용하여 $540 \mathrm{~nm}$ 에서 흡광도를 측정하였고 세포보호 효과는 시료의 흡광도를 대조군의 흡광도에 대한 백분율로 나타내었다.

\section{$\mathrm{NO}$ 생성량}

RAW264.7 세포를 $5 \times 10^{4} \mathrm{cell} / \mathrm{well}$ 가 되도록 96-well plate 에 각각 $100 \mu \mathrm{L}$ 씩 첨가하여 24시간 배양하고, 시료 및 lipopolysaccharides(LPS $0.1 \mathrm{\mu g} / \mathrm{mL}$, Sigma-Aldrich Co.)를 처리하여 24시간 배양하였다. 배양이 완료된 후 상등액 50 $\mu \mathrm{L}$ 에 동량의 griess(Sigma-Aldrich Co.)시약을 혼합하여 10 분간 반응 시킨 후 microplate reader(UVM-340, ASYS Co.) 를 이용하여 $540 \mathrm{~nm}$ 에서 흡광도를 측정하였으며 nitric oxide 생성량은 sodium nitrite(Sigma-Aldrich Co.)의 농도별 표준곡선을 이용하여 계산하였다.

\section{암세포 생존율}

배양된 4종의 암세포주 A549, SNU719, HeLa 및 MCF7을 $2 \times 10^{4} \mathrm{cell} / \mathrm{mL}$ 로 96 well plate에 각각 $100 \mu \mathrm{L}$ 씩 첨가하여 incubator에서 24시간 배양하고 시료를 각각 처리한 후 48시 간 동안 배양하였다. 배양 후 PBS 완충용액에 녹인 3-(4,5-dimethylthiazol-2-yl)-2,5-diphenyltetrazolium bromide(MTT $5 \mathrm{mg} / \mathrm{mL}$, Sigma-Aldrich Co.) 용액을 각 well 에 $10 \mu \mathrm{L}$ 씩 첨가하고 다시 4시간 동안 배양하여 MTT가 환원되도록 하였다. 배양종료 후 생성된 formazan 결정이 흐트러지지 않게 배양액을 완전히 제거하고 제거된 각 well 에 $100 \mu \mathrm{L}$ 씩의 dimethyl sulfoxide(DMSO)를 가하여 10 분간 반응시켜 formazan 결정을 용해한 후 microplate reader 
(UVM-340, ASYS Co.)를 이용하여 $540 \mathrm{~nm}$ 에서 흡광도를 측정하였다. 양성 대조군으로는 doxorubicin(DOX, SigmaAldrich Co.)을 $1 \mathrm{\mu g} / \mathrm{mL}$ 농도로 사용하여 비교하였다.

\section{통계 처리}

실험결과는 3회 반복실험의 평균표준편차로 나타내었 고 SPSS(19.0, SPSS Inc., Chicago, IL, USA)를 이용하여 분산분석(ANOVA)을 실시하였고 각 측정 평균값의 유의 성 $(\mathrm{p}<0.05)$ 은 Duncan's multiple range test로 검정하였다.

\section{결과 및 고찰}

\section{다당류의 이화학적 특성}

효소종류에 따른 불등풀가사리 유래 다당류의 수율, 총 당 함량, 단백질, uronic acid 및 sulfate 함량은 Table 1 과 같다. 효소종류(celluclast, flavourzyme, papain, termamyl, viscozyme)에 따른 불등풀가사리 다당의 수율은 효소 분해 구간에서 52.8-66.4\%를 나타내어 무처리 구간 50.6\%에 비 해 유의적으로 높은 수율을 나타내었으며, viscozyme 효소 분해 구간에서 가장 높은 수율을 나타내었다. 이는 Lee 등 (18)의 효소처리에 의한 참당귀 다당 분리 연구에서 viscozyme L 효소 처리구간에서 가장 높은 수율을 나타낸 다고 보고하여 본 연구결과와 유사한 경향을 나타내었다.

총 당 및 총 단백질 함량은 viscozyme 효소 분해 구간에서 각각 $71.04 \%$ 및 $7.22 \%$ 로 가장 높은 함량을 나타내었으며, 무처리 구간에서 각각 $61.54 \%$ 및 $5.39 \%$ 로 가장 낮은 함량 을 나타내었다. Uronic acid 및 sulfate 함량의 경우에도 viscozyme 효소 분해 구간에서 각각 $23.18 \mathrm{~g} / 100$ 및 $28.27 \%$ 의 함량을 나타내어 무처리 구간 $18.25 \mathrm{~g} / 100$ 및 $22.00 \%$ 보다 높은 함량을 나타내었다. 이러한 결과는 viscozyme 효소에 포함되어 있는 다양한 복합효소(arabanase, cellulase,
B-glucanase, hemi-cellulase, xylanase) 분해 작용에 의해 식 물 세포벽에 있는 성분을 분해하여 섬유질이나 당단백질 또는 고분자 물질 등의 활성물질들이 원활하게 추출될 수 있도록 유도하여 높은 수율과 생리활성을 나타낸 것으로 사료된다(19). 또한, Papain(단백질 중간부분에서 무작위로 분해하는 endoprotease) 및 flavourzyme(단백질 말단에서 아 미노산 단위로 분해하는 exoprotease)의 경우 단백질분해효 소 중 비교적 높은 가수분해효과를 나타내는 것으로 알려져 있으나(18), 불등풀가사리 다당류 추출을 위한 효소로는 효과적이지 않았으며 viscozyme 효소 분해를 통한 uronic acid 및 sulfate 함량 증가는 면역 및 항보체 활성과 항암 및 항혈전 효능 등의 생리활성을 나타낼 것으로 사료된다 $(20,21)$.

\section{항산화 활성}

불등풀가사리 유래 다당류의 항산화 활성을 확인하기 위해 DPPH radical 소거활성 및 ferric reducing antioxidant potential(FRAP)를 $5 \mathrm{mg} / \mathrm{mL}$ 농도에서 측정한 결과는 Fig. 1 과 같다. 효소 분해 구간의 DPPH radical 소거활성 및 FRAP는 각각 14.97-23.10\% 및 123.06-218.50 $\mathrm{MM}$ 를 나타내 어 무처리 구간 $10.55 \%$ 및 $102.44 \mu \mathrm{M}$ 에 비해 우수한 항산화 활성을 나타내었으며, viscozyme 효소 구간에서 가장 높은 항산화 활성을 나타내었다. 이는 다당류에 함유되어 있는 sulfate 함량이 항산화 활성을 나타내는 중요한 척도로 알려 져 있으며(22), Yang 등(23)의 홍조식물(참산호말)에서 추 출한 황산다당류의 항산화활성 연구에서 sulfate 함량이 높 은 구간에서 우수한 항산화 활성을 나타낸다고 보고하여 본 연구결과와 유사한 경향을 나타내었다. 또한, uronic acid 와 다당류간의 상호관계를 통해 항산화 활성 증진에 영향을 미친다고 알려져 있으나, 이러한 다당류의 항산화 활성은 하나의 단일 인자에 올리고머 중합체, sulfate 함량 및 당과 단백질 구성요소 작용에 의해 달라진다고 보고하였다(24).

Table 1. Yields, sugar, uronic acid, sulfate, and protein contents of polysaccharides from Gloiopeltis furcata

\begin{tabular}{cccccc}
\hline Samples $^{1)}$ & $\begin{array}{c}\text { Yield } \\
(\%)\end{array}$ & $\begin{array}{c}\text { Sugar content } \\
(\text { glucose, } \%)\end{array}$ & $\begin{array}{c}\text { Protein content } \\
\left(\mathrm{BSA}^{2)}, \%\right)\end{array}$ & $\begin{array}{c}\text { Uronic acid content } \\
\left(\mathrm{GA}^{3)}, \mathrm{g} / 100 \mathrm{~g}\right)\end{array}$ & $\begin{array}{c}\text { Sulfate content } \\
\left.\left(\mathrm{PS}^{4}\right), \%\right)\end{array}$ \\
\hline Control & 50.6 & $61.54 \pm 0.36^{\mathrm{s})}$ & $5.39 \pm 0.23^{\mathrm{c}}$ & $18.25 \pm 0.44^{\mathrm{d}}$ & $22.00 \pm 1.09^{\mathrm{d}}$ \\
Celluclast & 54.6 & $65.98 \pm 0.47^{\mathrm{bc}}$ & $6.48 \pm 0.32^{\mathrm{b}}$ & $21.97 \pm 0.70^{\mathrm{c}}$ & $26.30 \pm 0.73^{\mathrm{b}}$ \\
Flavourzyme & 52.8 & $63.05 \pm 0.41^{\mathrm{d}}$ & $2.63 \pm 0.62^{\mathrm{d}}$ & $18.27 \pm 0.55^{\mathrm{d}}$ & $24.65 \pm 0.66^{\mathrm{c}}$ \\
Papain & 57.8 & $65.46 \pm 1.44^{\mathrm{c}}$ & $5.31 \pm 0.19^{\mathrm{c}}$ & $19.36 \pm 0.67^{\mathrm{d}}$ & $22.76 \pm 0.36^{\mathrm{d}}$ \\
Termamyl & 63.8 & $67.09 \pm 0.74^{\mathrm{b}}$ & $5.55 \pm 0.19^{\mathrm{c}}$ & $22.87 \pm 0.87^{\mathrm{bc}}$ & $25.88 \pm 0.43^{\mathrm{b}}$ \\
Viscozyme & 66.4 & $71.04 \pm 0.67^{\mathrm{a}}$ & $7.22 \pm 0.17^{\mathrm{a}}$ & $23.18 \pm 0.42^{\mathrm{a}}$ & $28.27 \pm 0.61^{\mathrm{a}}$ \\
\hline
\end{tabular}

${ }^{1)}$ Control, polysaccharide isolated from non-enzyme treatment; Celluclast, polysaccharide isolated from celluclast enzyme treatment; Flavourzyme, polysaccharide isolated from flavourzyme enzyme treatment; Papain, polysaccharide isolated from papain enzyme treatment; Termamyl, polysaccharide isolated from termamyl enzyme treatment; Viscozyme, polysaccharide isolated from viscozyme enzyme treatment.

${ }^{2} \mathrm{BSA}$, bovine serum albumin.

${ }^{3)} \mathrm{GA}$, galacturonic acid.

${ }^{4)} \mathrm{PS}$, potassium sulfate

${ }^{5)}$ The values represent means $\pm S D \quad(n=3)$. Means with different superscripts in the same column are significantly different at $p<0.05$. 
따라서, 불등풀가사리에서 분리된 다당류에 함유되어 있는 uronic acid 및 sulfate 함량 증가와 다양한 구성 요소에 의해 항산화 활성이 증진된 것으로 사료된다.

(A)

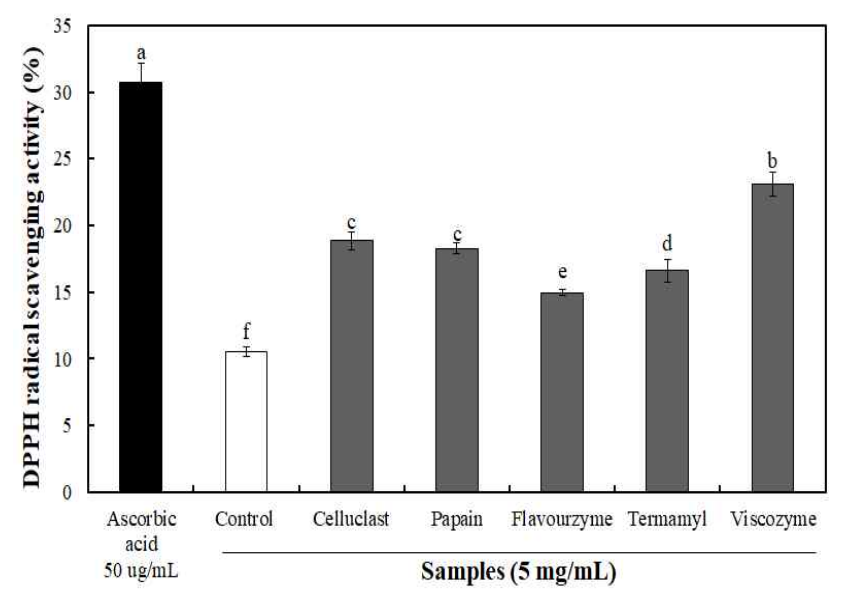

(B)

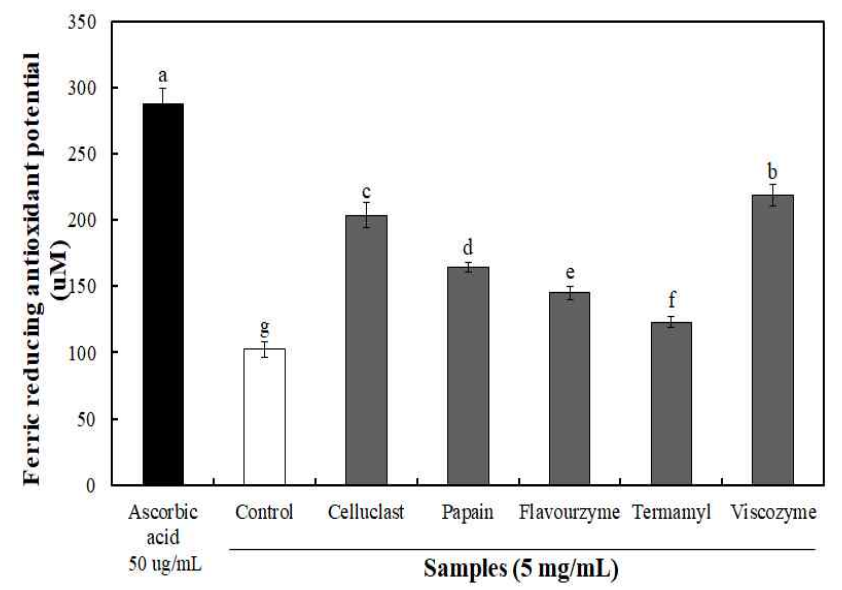

Fig. 1. DPPH radical scavenging activity and ferric reducing antioxidant potential of polysaccharides from Gloiopeltis furcata. (A), DPPH radical scavenging activity; (B), ferric reducing antioxidant potential. Control, polysaccharide isolated from non-enzyme treatment; Celluclast, polysaccharide isolated from celluclast enzyme treatment; Flavourzyme, polysaccharide isolated from flavourzyme enzyme treatment; Papain, polysaccharide isolated from papain enzyme treatment; Termamyl, polysaccharide isolated from termamyl enzyme treatment; Viscozyme, polysaccharide isolated from viscozyme enzyme treatment.

Means with different letters above the bars are significantly different at $\mathrm{p}<0.05$.

\section{산화적 손상에 대한 보호효과}

효소 종류에 따른 불등풀가사리 유래 다당류를 폐 정상 세포(L132)에 농도별로 처리하여 MTT 분석 방법으로 세포 독성을 측정한 결과(Fig 2), 다당류 0.1-1 $\mathrm{\mu g} / \mathrm{mL}$ 농도까지 유의적인 세포 사멸이 나타나지 않아 세포 독성이 없음을 확인하여 세포 보호 효과 실험 농도로 설정하였다.

불등풀가사리에서 분리된 다당의 산화적 손상에 대한 세포 보호효과를 알아보기 위하여, $\mathrm{H}_{2} \mathrm{O}_{2}$ 처리를 통한 $\mathrm{L} 132$ 세포에 산화적 손상을 유발 하였을 때 세포 생존율을 측정 하였다(Fig 2). 세포 보호 효과 실험에 사용되는 $\mathrm{H}_{2} \mathrm{O}_{2}$ 는
쉽게 원형질막을 통과하기 때문에 in vitro 또는 in vivo 실험 의 다양한 생리학적 및 병리학적 조건에서 산화적 손상을 유발하는 독성 물질로 많이 이용되고 있다(25).

이러한 산화적 손상에 대한 불등풀가사리 유래 다당의 세포 보호 효과는 $1 \mathrm{\mu g} / \mathrm{mL}$ 농도에서 효소처리에 의해 분리 된 다당류의 경우 71.89-85.64\%의 보호 효과를 나타내어 무처리 구간 $61.30 \%$ 에 비해 높은 세포 보호 효과를 나타내 었으며, Cho 등(26)은 $\mathrm{H}_{2} \mathrm{O}_{2}$ 에 의해 유도된 산화적 스트레스 에 대한 블랙베리의 세포보호효과 연구에서 세포 보호효과 는 항산화활성과 유사한 경향을 나타내는 것으로 보고하였 다. 따라서 불등풀가사리 유래 다당이 $\mathrm{H}_{2} \mathrm{O}_{2}$ 처리로 인해 발생하는 산화적 스트레스를 감소시킴으로써 세포생존율 을 증가시키는 것으로 판단된다.

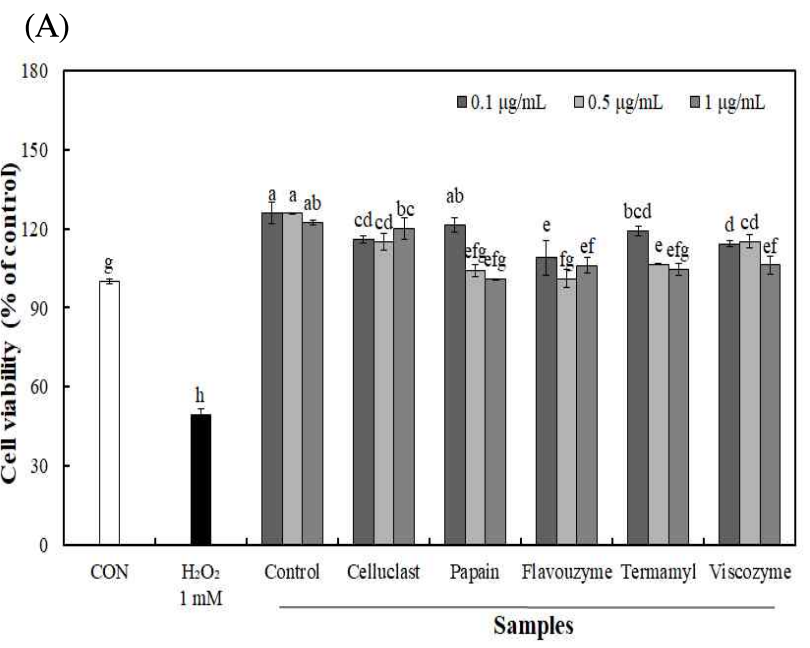

(B)

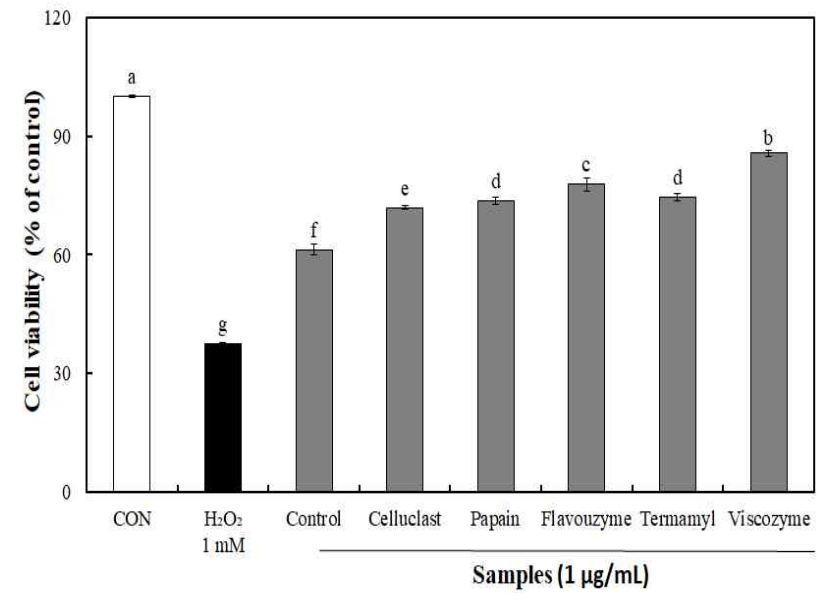

Fig. 2. Effect of polysaccharides from Gloiopeltis furcata on the cell viability of L-132 cell.

(A), cytotoxicity; (B), Protective effect against $\mathrm{H}_{2} \mathrm{O}_{2}$-induced cytotoxicity. Control, polysaccharide isolated from non-enzyme treatment; Celluclast, polysaccharide isolated from celluclast enzyme treatment; Flavourzyme, polysaccharide isolated from flavourzyme enzyme treatment; Papain, polysaccharide isolated from papain enzyme treatment; Termamyl, polysaccharide isolated from termamyl enzyme treatment; Viscozyme, polysaccharide isolated from viscozyme enzyme treatment.

Means with different letters above the bars are significantly different at $p<0.05$. 


\section{$\mathrm{NO}$ 생성량}

효소 종류에 따른 불등풀가사리 유래 다당류를 대식세포 (RAW264.7) 세포에 농도별로 처리하여 MTT 분석 방법으 로 세포 독성을 측정한 결과(data not shown), 다당류 0.1-5 $\mathrm{\mu g} / \mathrm{mL}$ 농도까지 유의적인 세포 사멸이 나타나지 않아 세포 독성이 없음을 확인하여 면역증강 세포실험의 농도로 설정 하였다.

대식세포는 아주 오래전부터 숙주방어 및 선천 면역반응 에 중요한 역할을 하고 있으며, 대식세포의 활성화는 병원 균 감염에 대한 자기방어 방법 중 하나로 알려져 있다(27). $\mathrm{NO}$ 생성량은 효소 분해를 통해 분리된 다당에서 15.67-20.93 $\mu \mathrm{M}$ 을 나타내어 무처리 다당 $14.63 \mu \mathrm{M}$ 에 비해 높은 생성량을 나타내었다(Fig. 3). 가장 높은 NO 생성량을

(A)

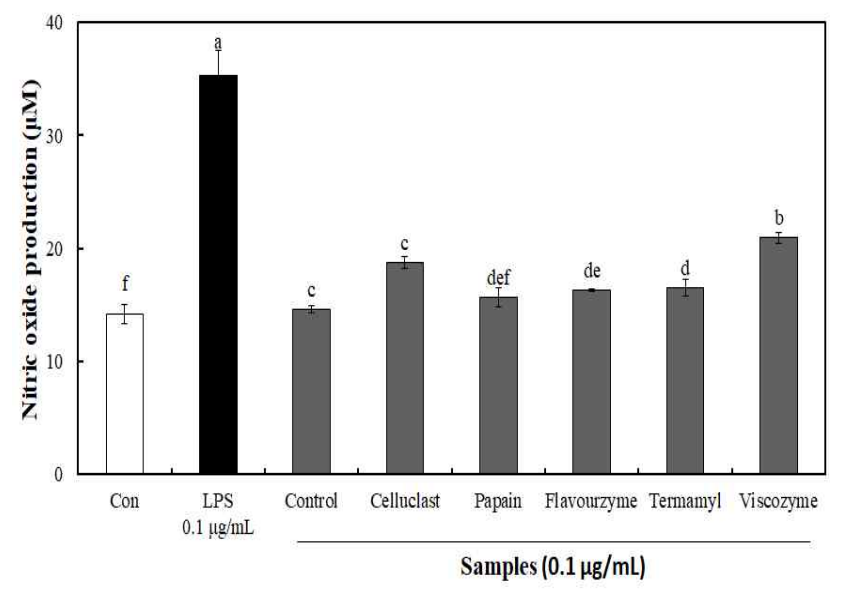

(B)

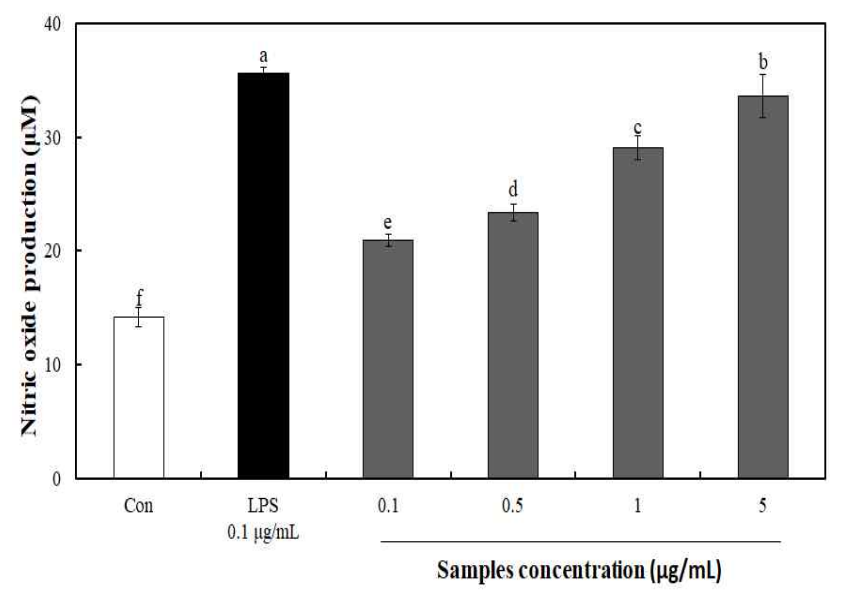

Fig. 3. Nitric oxide production of polysaccharides from Gloiopeltis furcata.

(A), enzymes; (B), viscozymes.

Control, polysaccharide isolated from non-enzyme treatment; Celluclast, polysaccharide isolated from celluclast enzyme treatment; Flavourzyme, polysaccharide isolated from flavourzyme enzyme treatment; Papain, polysaccharide isolated from papain enzyme treatment; Termamyl, polysaccharide isolated from termamyl enzyme treatment; Viscozyme, polysaccharide isolated from viscozyme enzyme treatment.

Means with different letters above the bars are significantly different at $p<0.05$.
나타낸 viscozyme 효소 분해 구간의 경우 0.1-5 $\mu \mathrm{g} / \mathrm{mL}$ 농도 에서 NO 생성량(20.93-32.13 $\mu \mathrm{M})$ 이 농도 유의적으로 증가 함을 확인하였으며 $5 \mathrm{\mu g} / \mathrm{mL}$ 농도에서 양성대조군으로 사 용한 LPS $(0.1 \mu \mathrm{g} / \mathrm{mL})$ 의 약 $90 \%$ 생성량을 나타내어 불등풀 가사리 유래 다당의 우수함을 확인하였다. 일반적으로 해 조류 유래 황함 다당류는 항암 및 면역증진 효능이 우수한 것으로 알려져 있으며(28), Leiro 등(29)의 해조류(Ulva rigida) 유래 황산다당류의 면역 활성 연구에서 NO 생성량 은 황산기 함량과 비례한다고 보고하였으며, 또한, Lee 등 (30)의 우렁쉥이 껍질 다당 추출물의 면역증강 연구에서 대식세포에 시료를 처리한 결과 농도가 증가함에 따라 $\mathrm{NO}$ 생성량이 증가하였다는 결과와 유사한 경향을 나타내었다. 따라서, 불등풀가사리 유래 다당류는 높은 NO 생성량을 통해 면역 세포를 활성화시켜 싸이토카인 분비촉진, 대 식세포 및 보체시스템의 활성화 등에 관여할 것으로 사 료된다.

\section{암세포 저해율}

4종의 암세포주 인간 폐암세포(A549), 인간 위암세포 (SNU719), 인간 자궁경부암세포(HeLa) 및 인간 유방암세 포(MCF7)에 대한 불등풀가사리 유래 다당류의 암세포 저 해율은 Fig. 4와 같다. 4종의 암세포주에 시료를 $5-25 \mu \mathrm{g} / \mathrm{mL}$ 농도로 가한 후 48 시간 배양한 결과 $5 \mu \mathrm{g} / \mathrm{mL}$ 이상의 농도에 서 유의적인 암세포 생존 저해율을 확인 할 수 있었으며 농도가 증가함에 따라 유의적으로 생존 저해 효과를 나타내 었다. Viscozyme 효소 분해를 통해 분리된 다당 $25 \mu \mathrm{g} / \mathrm{mL}$ 농도에서 A549, SNU719, HeLa 및 MCF7 암세포주 저해 효과는 각각 $69.57 \%, 61.06 \%, 52.74 \%$ 및 $68.64 \%$ 를 나타내 었으며, 무처리 구간의 경우 $78.89 \%, 83.19 \%, 71.05 \%$ 및 $82.65 \%$ 를 나타내었다. 이러한 결과를 통해 효소 분해를 통해 분리된 다당의 경우 농도 의존적으로 낮은 암세포 성장률을 나타내었으며, 그 중 viscozyme 효소 처리 구간에 서 다른 구간에 비해 낮은 암세포 생존율을 확인하여 암세 포 성장 억제효과가 높게 나타나는 것을 확인 할 수 있었다. 암은 세포의 증식이 비정상적으로 증가되거나 adopotosis 가 적절하게 이루어지지 않고 감소하는 경우에 발생되는 데, 인체의 면역조절 작용에서 대식세포는 암세포를 억제 하는 항암효과를 나타내며 NO, cytokine 등이 중요한 역할 을 하는 것으로 알려져 있다(31). 또한, Park 등(7)의 불등풀 가사리 분획물의 암세포 성장 억제효과 연구에서 여성암인 유방암과 자궁경부암에 효과가 탁월하다고 보고하여 본 연구결과와 유사한 경향을 나타내었으며, NO 생성량 증가 를 통해 대식세포의 탐식능을 증가시키고 항암활성을 증가 시킨 것으로 사료된다. 
(A)

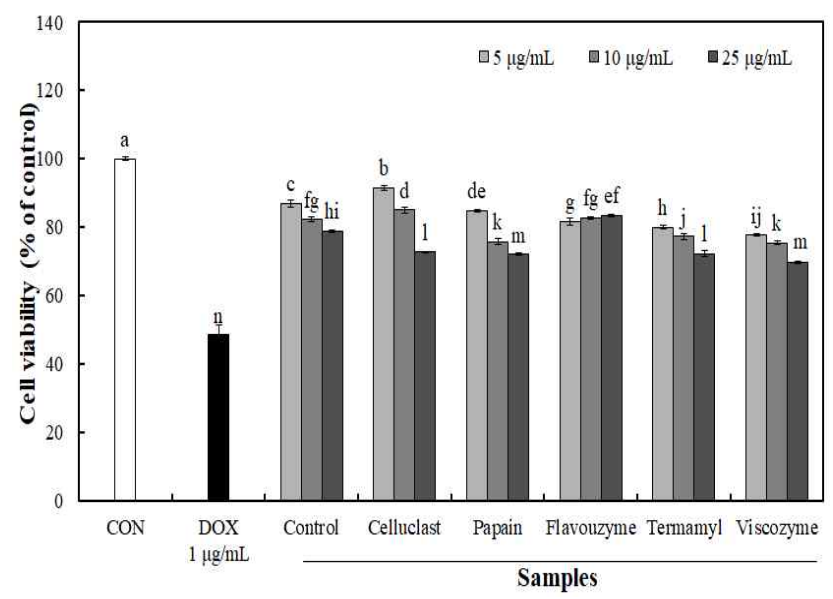

(C)

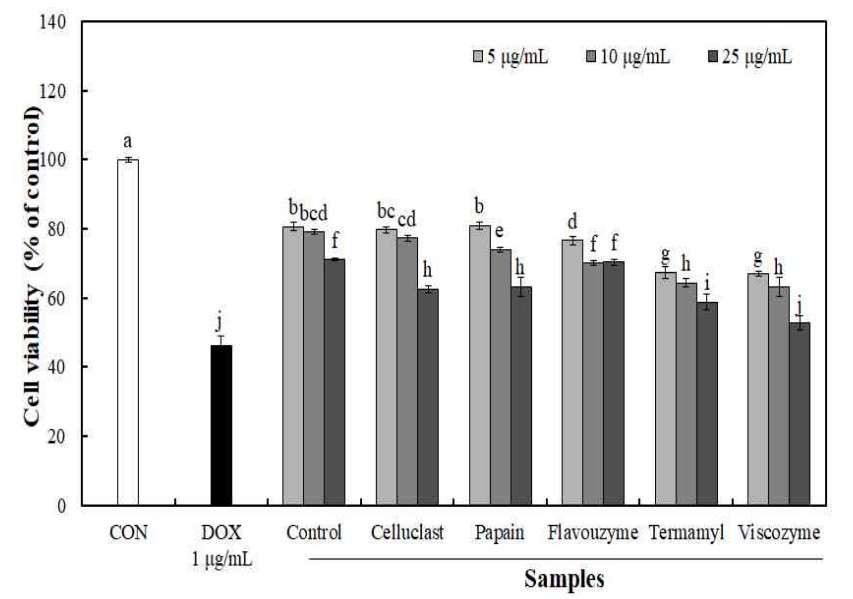

(B)

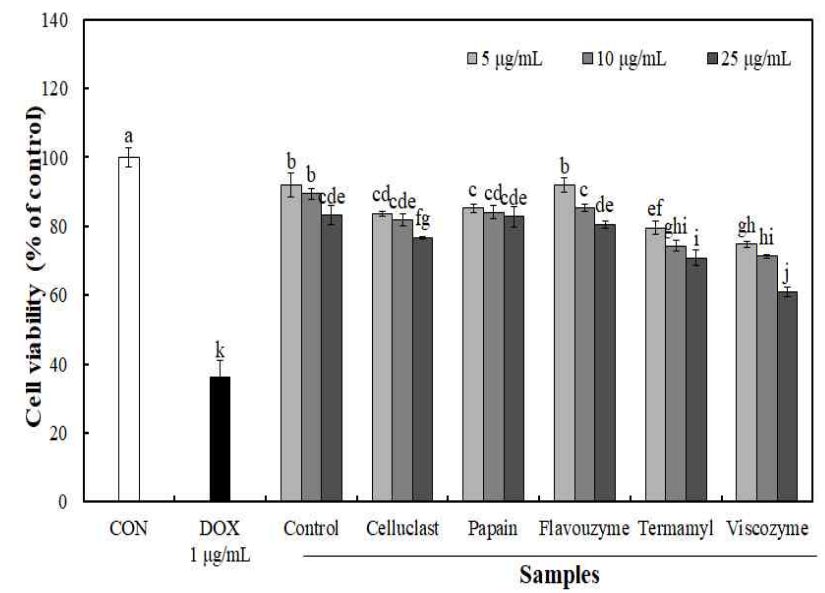

(D)

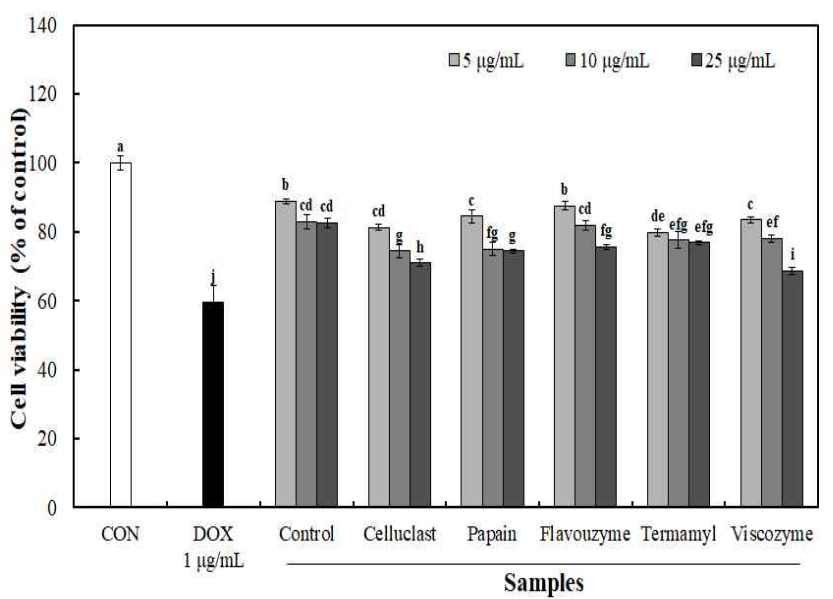

Fig. 4. Antitumor activity of polysaccharides from Gloiopeltis furcata.

(A), A549; (B), SNU719; (C), HeLa; (D), MCF7.

Control, polysaccharide isolated from non-enzyme treatment; Celluclast, polysaccharide isolated from celluclast enzyme treatment; Flavourzyme, polysaccharide isolated from flavourzyme enzyme treatment; Papain, polysaccharide isolated from papain enzyme treatment; Termamyl, polysaccharide isolated from termamyl enzyme treatment; Viscozyme, polysaccharide isolated from viscozyme enzyme treatment.

Means with different letters above the bars are significantly different at $p<0.05$.

\section{요 약}

본 연구에서는 불등풀가사리 유래 다당류의 기능성식품 소재로의 활용성을 향상시키고자 불등풀가사리에 5 종의 상업용 효소를 처리한 다음 분리된 다당류의 이화학적 특성 및 생리활성을 조사하였다. 효소 분해 구간의 다당 수율은 52.8-66.4\%로 무처리 구간 50.6\%에 비해 유의적으로 증가 하였다. 이화학적 특성으로 총당 및 단백질 함량은 각각 $71.04 \%$ 및 7.22\%, uronic acid 및 sulfate 함량은 $23.18 \mathrm{~g} / 100$ $\mathrm{g}$ 및 28.27\%로 효소 분해를 통해 증가하였다. DPPH radical 소거활성 및 $\mathrm{FRAP}$ 에 의한 항산화 활성은 $23.10 \%$ 및 218.50 $\mu \mathrm{M}$ 을 나타내어 무처리 구간에 비해 항산화 활성이 우수하 였으며, L132 세포 사멸에 대한 보호효과는 viscozyme 효소 처리 구간 $(1 \mu \mathrm{g} / \mathrm{mL})$ 에서 $\mathrm{H}_{2} \mathrm{O}_{2}$ 를 처리한 구간 대비 세포
보호효과는 $85.64 \%$ 로 세포 활성이 증가하여 높은 세포 보 호효과를 나타내었다. NO 생산량은 viscozyme 효소 처리 구간 $5 \mathrm{\mu g} / \mathrm{mL}$ 농도에서 $32.13 \mu \mathrm{M}$ 함량을 나타내어 LPS 대비 $90 \%$ 높은 생성량을 나타내었으며, 4종의 암세포 (A549, SNU719, HeLa 및 MCF7) 생존율은 $25 \mathrm{\mu g} / \mathrm{mL}$ 농도에 서 각각 $69.57 \%, 61.06 \%, 52.74 \%$ 및 $68.64 \%$ 의 유의적으로 낮은 암세포 생존율을 나타내었다. 따라서 불등풀가사리의 효소 분해를 통해 다당의 이화학적 특성 및 생리활성이 향상됨에 따라 기능성 식품소재 로 다양하게 활용 가능할 것으로 사료된다.

\section{References}

1. Byun HG, Kim SK (2005) Trend and prospect of marine 
bioindustry. Food Industry and Nutrition, 10, 32-39

2. Ruiz-Ruiz F, Mancera-Andrade EI, Iqbal HMN (2017) Marine-derived bioactive peptides for biomedical sectors: A review. Protein Pept Lett, 24, 109-117

3. Schachat RE, Glicksman M (1959) Some lesser known seaweed extracts. Academic Press, New York, NY, USA, P 135-191

4. Ito K, Hori K (1989) Seaweed: Chemical composition and potential food uses. Food Rev Int, 5, 101-144

5. Lee SB, Cho SJ, Lee SY, Paek KH, Kim JA, Chang JH (2009) Present status and prospects of marine chemical bioindustries. KSBB J, 24, 495-507

6. Hong CH, Kim SW, Kim YW, Park HD, Shin HJ (2014) Industrial applications of saccharification technology for red seaweed polysaccharide. KSBB J, 29, 307-315

7. Park SY, Jung BM, Choi YH, Bae SJ (2005) Growth inhibition effects of cancer cell lines by Gloiopeltis furcata fractions in vitro. J Korean Soc Food Sci Nutr, 34, 771-775

8. Wang X, Wang J, Zhang J, Zhao B, Yao J, Wang Y (2010) Structure-antioxidant relationships of sulfated galactomannan from guar gum. Int J Biol Macromol, 46, 59-66

9. Kim JH, Kim YH, Kim SK, Kim BW, Nam SW (2011) Properties and industrial applications of seaweed polysaccharides-degrading enzymes from the marine microorganisms. Korean J Microbiol Biotechnol, 39, 189-199

10. Uo MH, Joo DS, Cho SY, Min TS (2006) Purification and characterization of the extracellular alginase produced by Bacillus licheniformis AL-577. J Korean Soc Food Sci Nutr, 35, 231-237

11. Heo SJ, Jeon YJ (2005) Antioxidant effect and protecting effect against cell damage by enzymatic hydrolysates from marine algae. Food Industry and Nutrition, 10, 31-41

12. Saha SK, Brewer CF (1994) Determination of the concentrations of oligosaccharides, complex type carbohydrates, and glycoproteins using the phenolsulfuric acid method. Carbohydr Res, 254, 157-167

13. Lowry OH, Rosebrough NJ, Farr AL, Randall RJ (1951) Protein measurement with the folin phenol reagent. J Biol Chem, 193, 265-275

14. Cesaretti M, Luppi E, Maccari F, Volpi N (2003) A 96-well assay for uronic acid carbazole reaction. Carbohydr Polym, 54, 59-61

15. Dodgson KS, Price RG (1962) A note on the determination of the ester sulphate content of sulphated polysaccharides. Biochem J, 84, 106-110

16. Blois MS (1958) Antioxidant determinations by the use of a stable free radical. Nature 181, 1199-1200

17. Benzie IFF, Strain JJ (1996) The ferric reducing ability of plasma (FRAP) as a measure of "antioxidant power" the FRAP assay. Anal Biochem, 230, 70-76

18. Lee HJ, Jeong HS, Park CG, Lee JH, Park CB, Kim CT, Choi AJ (2014) A study on isolation of polysaccharides from Angelica gigas Nakai by enzyme treatments. Food Eng Prog, 18, 406-412

19. Lee JY, Chae SK (2010) Studies on the changes in the extraction of phenolics and color characteristics by the enzyme treatment of red grape (Muscat Bailey A) wine during fermentation. Korean J Food Nutr, 23, 324-331

20. Kumar V, Nagar S, Tripathi YC (2014) Do assorted approaches aid in estimation of uronic acids? Case studies on Tinospora sinensis polysaccharides. Int $\mathrm{J}$ Biol Macromol, 70, 360-363

21. Tao Y, Zhang Y, Zhang L (2009) Chemical modification and antitumor activities of two polysaccharide-protein complexes from Pleurotus tuber-regium. Int $\mathrm{J}$ Biol Macromol, 45, 109-115

22. Wang X, Zhang Z, Yao Z, Zhao M, Qi H (2013) Sulfation, anticoagulant and antioxidant activities of polysaccharide from green algae Enteromorpha linza. Int $\mathrm{J}$ Biol Macromol, 58, 225-230

23. Yang Y, Liu D, Wu J, Chen Y, Wang S (2011) In vitro antioxidant activities of sulfated polysaccharide fractions extracted from Corallina officinalis. Int J Biol Macromol, 49, 1031-1037

24. Chen H, Zhang M, Xie B (2004) Quantification of uronic acids in tea polysaccharide conjugates and their antioxidant properties. J Agric Food Chem, 52, 3333-3336

25. Kim MJ, Lee SP, Choi JH, Kwon SH, Kim HD, Bang MH, Yang SA (2013) Characteristics of fermented dropwort extract and vinegar using fermented dropwort extract and its protective effects on oxidative damage in rat glioma C6 cells. Korean J Food Sci Technol, 45, 350-355

26. Cho BO, Lee CW, So Y, Jin CH, Yook HS, Byun MW, Jeong YW, Park JC, Jeong IY (2014) Protective effect of radiation-induced new blackberry mutant $\gamma$-B201 on $\mathrm{H}_{2} \mathrm{O}_{2}$-induced oxidative damage in HepG2 cells. Korean J Food Sci Technol, 46, 384-389

27. Wang ML, Hou YY, Chiu YS, Chen YH (2013) Immunomodulatory activities of Gelidium amansii gel extracts on murine RAW264.7 macrophages. J Food Drug 
Anal, 21, 397-403

28. Park JS, Kim A, Kim EH, Suh HS, Choi WC (2002) Increased anticancer activity by the sulfated fucoidan from Korean brown seaweeds. J Korean Chem Soc, 46, 151-156

29. Leiro JM, Castro R, Arranz JA, Lamas J (2007) Immunomodulating activities of acidic sulphated polysaccharides obtained from the seaweed Ulva rigida C. Agardh. Int Immunopharmacol, 7, 879-888
30. Lee DH, Hong JH (2015) Immune-enhancing effects of polysaccharides isolated from ascidian (Halocynthia roretzi) Tunic. J Korean Soc Food Sci Nutr, 44, 673-680

31. Hamsa TP, Kuttan G (2011) Evaluation of the antiinflammatory and anti-tumor effect of Ipomoea obscura (L) and its mode of action through the inhibition of pro inflammatory cytokines, nitric oxide and COX-2. Inflammation, 34, 171-183 